\title{
The Antecedent Factor of Employee Engagement from a Self-Determination Theory Perspective
}

\author{
Cattleya Rejito \\ Graduate of Management and Business \\ Universitas Padjadjaran \\ Indonesia \\ cattleyarejito@gmail.com
}

\author{
Mery Citra Sondari \\ Department of Management and Business \\ Universitas Padjadjaran \\ Indonesia \\ mery.sondari@unpad.ac.id
}

\begin{abstract}
Many studies have explained both motivation and employee engagement, however, very few studies explained the relationship of employee engagement towards motivation using perspectives from self-determination theory. The aim of the research is to explain the motivation that seen from perspective of self-determination theory by linked it to the employee engagement. This research use 69 samples who are employees in a company who served installation for telecommunication equipment. Using Partial Least Square, result from this research show the influence of selfdetermination theory towards employee engagement is very high.
\end{abstract}

Keywords- employee engagement, self-determination theory, extrinsic motivation, intrinsic motivation

\section{INTRODUCTION}

Employee engagement is one of the many efforts to describe psychological presences of the employees toward company. The performance of the employee will get highest result if they supported by employer that could managed their engagement so the company or organization could maintain the ability and capability of the employees in order to achieve goals. In order to achieve company's success the employee should be feeling that they has been perform maximum performance so then they could stay within the organization and company could maximized their profit. Employee engagement also supported by factor that became really essential for employees to have for complete the terms of engaged employees. The factor is education. The more educated employees the less engaged feeling that they have towards company.

To create highly engaged employees, there are several factors that support employee to be engaged with their company. Start from focusing, fulfil then make employees satisfied on their basic needs such as salaries and benefits. Employee next will look forward to development opportunities such as promotion and training program to develop their skills [1]. By complete all of the employees' needs, not only the employees that fill satisfied with their needs, but also the company because finally company will have employees' that feel engaged to the job and ready to devoted themselves to the company.

But it is not enough by only fulfilling employees' need and developing their skills. As the key to all company other role should use in this problem. Other role that can be used to engage employee is motivation [2]. Motivation and engagement has relationship because motivation means producing something with engagement [3]. In previous explanation about engagement, there are several factors that will support the employees to feel engaged to the company. Those factors also came up in motivation as the factors that can be used to motivate an individual. So there are some similar factor in motivation and engagement.

Motivation can be describe by two factors; internal and external. Further know by intrinsic and extrinsic motivation. In intrinsic motivation, someone motivated to do something because they have internal desires such as fulfilling their needs, they like to do the actions because of they enjoy the activity or because they have specific lifestyle that they want to achieve. But for extrinsic motivation, they do their actions or job because of they get incentive from external such as rewards, salaries, bonus, or by doing their actions someone will recognize they action and give appreciation.

The focus on this research is to describe and see the correlation between employee engagement and motivation using perspective from self-determination theory.

\section{LITERATURE}

\section{Employee Engagement}

Personal engagement is individual that has specific role in their organization showed it by physically, cognitively and emotionally that can be seen clearly from their performance while working the job. Kahn focuses to defined engagement from psychological perspective. Because engagement can be seen from attitude and behaviour, the behaviour of engagement itself can be defines as the behaviour or attitude that come naturally from our self. Employee engagement is a condition of an individual when they show energy and passion to their job and organizations [4]. It can be seen both emotionally and intellectually while an individual performing their job.

From several explanations about definition of engagement, author conclude that employee engagement is energy, passion and behaviour of the employee shows by their committed both to their working responsibility and their organization and have several psychological factor come from individual itself further can be seen by other people or in this case organization. 
Three dimensions have been explained as physical, emotional and cognitive [5]. Those three dimensions explain as psychological dimension that will affect engagement. Engagement is the opposite concepts of burnout and can be measure independently using different instruments [6]. Dimensions that underlying in engagement have been identifies such as work-related and well-being. These dimensions consist of three dimensions opposite from burnout. There are vigour, dedication and absorption. The dimensions that explain in the research consist of three [7]. There are cognitive, emotional and behavioural. The dimensions are associated with the individual role performance.

From different explanation about employee engagement dimension, author seeks to the dimension that indicator which is related to the sample of research. In this case, the research is taking in medium company which is most of the employee background education is not so high. So the physical dimension will describe using energetic, durability, effort and resilient indicator. Emotional dimension describe using excitement, pride, value and challenge. The last dimension which is emotional dimension using indicator of focus, immerse and enjoyment.

\section{Self-determination Theory}

Self-determination theory is theory that combines several factors such as knowledge, skills and belief in order to create individual behaviour such as pursuing goal, self-directed, and autonomous behaviour [8]. Other definition by Deci and Ryan, explains Self-Determination theory as the theory of motivation, self-development and wellness of individual [9]. Based on explanation above, author conclude that selfdetermination is the act based on motivation and personality while individuals are faced several decision to be take in order to choose best decision for their lives, there are other factors from internal and external that will affect the decision making. The decision making proses needs analysis of strength and limitation that an individual have.

Master student from Umea University in Sweden has been researched about the relationship between intrinsic motivation and extrinsic motivation [2]. The result shows that there is positive relationship in between sub-variable of motivation and employee engagement variable. But in their research, employee engagement did not use any dimensions as author write in this research. The employee engagement only describe as the general variable without mention any dimensions to support the variable. Previous research use several perspective such as Maslow's Need Theory, Alderfer ERG Theory, Herzberg's two factor Theory, Four-Drive Theory and Self-Determination Theory. In this research, author will only focus on Self-Determination Theory to explain motivation theory.

\section{RESEARCH METHODOLOGY}

\section{Variables}

In this research, there are two independent variables and one dependent variable. Independent variable used for this research is Self-Determination Theory, which consist of two sub-variables:
- Intrinsic Motivation

- Extrinsic Motivation

Dependent Variable used for this research is employee engagements, which consist of three dimensions:

- Physical Dimensions

- Emotional Dimensions

\section{- Cognitive Dimensions}

The table below explain the dimensions and indicators that used in this research. The indicators are used to create the questionnaire in order to measure the influences of selfdetermination towards employee engagement.

TABLE I. VARIABLE OPERATIONS OF SELF-DETERMINATION THEORY

\begin{tabular}{|c|c|c|}
\hline Sub-variable & Dimension & Indicator \\
\hline \multirow{11}{*}{$\begin{array}{l}\text { Intrinsic } \\
\text { Motivation }\end{array}$} & \multirow{2}{*}{ Self-goal } & Task goals \\
\hline & & Ego goals \\
\hline & \multirow{2}{*}{ Pleasure } & Happiness \\
\hline & & Intellectual stimulation \\
\hline & \multirow{5}{*}{ Job Characteristic } & Skill variety \\
\hline & & Task identity \\
\hline & & Task significance \\
\hline & & Autonomy \\
\hline & & Feedback \\
\hline & Growth & Improvement \\
\hline & Recognition & Self-esteem \\
\hline \multirow{5}{*}{$\begin{array}{l}\text { Extrinsic } \\
\text { Motivation }\end{array}$} & $\begin{array}{l}\text { Non-monetary } \\
\text { Facility }\end{array}$ & Working condition \\
\hline & Incentive & Salary \\
\hline & \multirow[t]{2}{*}{ Supervisor } & $\begin{array}{l}\text { Interpersonal } \\
\text { understanding }\end{array}$ \\
\hline & & Achieving goals \\
\hline & Status & Others' view \\
\hline
\end{tabular}

TABLE II. VARIABLE OPERATIONS OF EMPLOYEE ENGAGEMENT

\begin{tabular}{|c|c|c|}
\hline Variables & Dimension & Indicator \\
\hline \multirow{12}{*}{$\begin{array}{c}\text { Employee } \\
\text { Engagement }\end{array}$} & \multirow{4}{*}{ Physical } & Energetic \\
\hline & & Durability \\
\hline & & Effort \\
\hline & & Resilient \\
\hline & \multirow{4}{*}{ Emotional } & Excitement \\
\hline & & Pride \\
\hline & & Value \\
\hline & & Challenge \\
\hline & \multirow{4}{*}{ Cognitive } & Persevere \\
\hline & & Focus \\
\hline & & Involvement \\
\hline & & Enjoyment \\
\hline
\end{tabular}




\section{RESULT AND CONCLUSION}

It can be seen from the figure using SmartPLS software below that extrinsic motivation has the highest score value compare to the intrinsic motivation. This show that extrinsic motivation have higher influence towards employee engagement compare to intrinsic motivation. It means that in the company, employee mostly influenced by extrinsic supervisor, office facilities and external perception affect employee's motivation while doing their job in company.

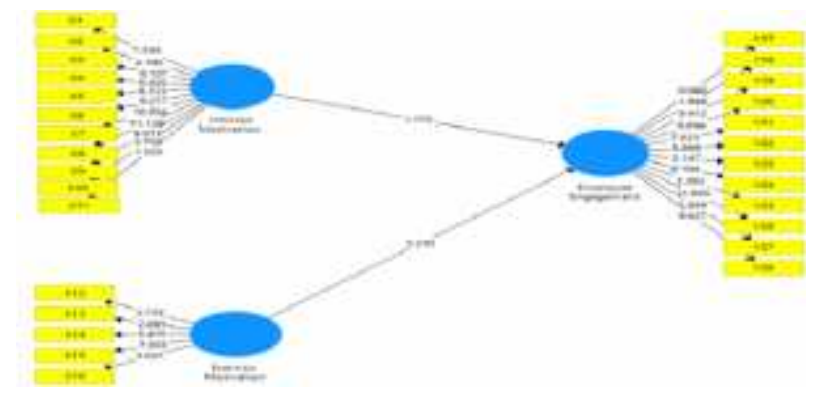

Fig. 1. Output Bootstrapping using SmartPLS Software

Source: Data Result

The table below shows that the relation between intrinsic motivation is positive but it is significant with T-statistic is $1.838(<1.96)$ and original sample estimate is positive which has value 0.244 . The relation between extrinsic motivation and employee engagement is positive and significant with T-statistic is $5.304(>1.96)$ and original sample estimate is positive which has value 0.566 .

Based on the original sample estimate, it can be seen that extrinsic motivation has the highest score compared to the intrinsic motivation which has value 0.566 . It means that extrinsic motivation has the highest influence for the employee engagement then follows by intrinsic motivation. But for the influence intrinsic motivation is not significant as the extrinsic motivation.

TABLE III. HYPOTHESIS TEST

\begin{tabular}{|c|l|c|c|c|}
\hline & $\begin{array}{c}\text { Orig } \\
\text { inal } \\
\text { Sam } \\
\text { ple } \\
(\mathbf{O})\end{array}$ & $\begin{array}{c}\text { Sam } \\
\text { ple } \\
\text { Mea } \\
\mathbf{n} \\
(\mathbf{M})\end{array}$ & $\begin{array}{c}\text { Standa } \\
\text { rd } \\
\text { Error } \\
\text { (STER } \\
\mathbf{R})\end{array}$ & $\begin{array}{c}\mathbf{T} \\
\text { Statisti } \\
\mathbf{c s} \\
(\mathbf{| O / S} \\
\text { TERR } \\
\mid)\end{array}$ \\
\hline $\begin{array}{c}\text { Intrinsic } \\
\text { Motivation - } \\
\text { > Employee } \\
\text { Engagement }\end{array}$ & 0.24 & 0.22 & 0.133 & 1.838 \\
\hline $\begin{array}{c}\text { Extrinsic } \\
\text { Motivation - } \\
\text { > Employee } \\
\text { Engagement }\end{array}$ & 0.56 & 0.60 & 0.107 & 5.304 \\
\hline
\end{tabular}

From the table III, it shows that correlation multiple $\mathrm{R}$ is 0.693, it means that the influence of self-determination theory towards employee engagement is very high. Other than that, also there is result of coefficient determination which R2 is 0.480 or $48 \%$. It means that the influence of self-determination which describe by intrinsic and extrinsic motivation is $48 \%$ and the rest $46.4 \%$ is influenced by the factors which not used in this model.

TABLE IV. HyPOTHESIS TEST RESULT

\begin{tabular}{|c|c|l|l|l|}
\hline $\begin{array}{c}\text { Mod } \\
\text { el }\end{array}$ & R & R Square & $\begin{array}{c}\text { Adjusted R } \\
\text { Square }\end{array}$ & $\begin{array}{l}\text { Std. Error of } \\
\text { the Estimate }\end{array}$ \\
\hline 1 & $693^{\mathrm{a}}$ & .480 & .464 & 6.949 \\
\hline
\end{tabular}

This research also analyses influence extrinsic and intrinsic motivation towards employee engagement simultaneously using coefficient of determination $\left(\mathrm{R}^{2}\right)$.

\section{CONCLUSION}

From the result of the research, it shows positive relationship with employee engagement. In conclusion, extrinsic motivation shows more significant and higher result than intrinsic motivation. From the statistical analyses author conclude that extrinsic motivation have higher impact towards employee engagement. It means that company and other external factor already provide good condition to motivate the employees.

\section{BIBLIOGRAPHY}

[1] M. S. Sridevi and S. M. Kompasi, "Employee Engagement: The Key to Improving Perfomance," International Journal of Business and Management, pp. 89-96, 2010.

[2] W. Khan and Y. Iqbal, "An Investigation of The Relationship Between Work Motivation (Intrinsic \& Extrinsic) and Employee Engagement: A Study on Allied Bank of Pakistan," Umea School of Business Umea University, Umea, Sweden, 2013.

[3] G. Crookes and R. Schmidt, "Language Learning," Journal of Research in Language Studies, pp. 469-512, 1991.

[4] R. Baumruk, "The missing link: the role of employee engagement in business successes," Workspan, vol. 47, pp. 48-52, 2004.

[5] W. A. Kahn, "Psychological Conditions of Personal Engagement and Disengagement at Work," Academy of Management Journal, vol. 33, no. 4, p. 692, December 1990.

[6] W. B. Schaufeli, M. Salanova, V. Gonzalez-Roma and A. B. Bakker, "The Measurement of Engagement and Burnout: A Two Sample Confirmatory of Analytic Approach," Journal of Happiness Studies, pp. 71-92, 2002.

[7] A. M. Saks, "Antecedents and consequences of employee engagement," Journal of Managerial Psychology, vol. 21, no. 7, pp. 600-619, 2006.

[8] S. Field, J. Martin, R. Miller, M. Ward and M. Wehmeyer, A practical guide to teaching self-determination, Austin: TX: PRO-ED, 1998. 
[9] E. L. Deci and R. M. Ryan, "Self-Determination Theory: A Macrotheory of Human Motivation, Development and Health," Canadian Psychology, vol. 49, no. 3, pp. 182-185, 2008.

[10] V. Barkoukis, H. Tsorbatzoudis, G. Grouios and G. Sideridis, "The assessment of intrinsic and extrinsic motivation and amotivation: Validity and reliability of the Greek version of the Academic Motivation Scale," Assesment in Education: Principles, Policy \& Practice, vol. 15, no. 1, pp. 39-55, March 2008.

[11] M. Csikszentmihalyi, Flow. The Psychology of Optimal Experience, New York: Harper, 1990.

[12] E. L. Deci and R. M. Ryan, "The "What" and "Why" of Goal Pursuits: Human Needs and Self-Determination of Behavior," Psychologival Inquiry, vol. 11, no. 4, pp. 227-268, 2000.

[13] M. Gagne and E. L. Deci, "Self-determination theory and work motivation," Journal of Organizational Behavior, pp. 331-362, 2005.

[14] I. Ghozali, Partial Least Square Konsep, Teknik dan Aplikasi, Semarang: Badan Penerbit Universitas Diponegoro, 2014.

[15] J. R. Hackman and G. R. Oldham, "Motivation Through The Design of Work: Test of a Theory.," Organizational Behavior and Human Performance, vol. 16, pp. 250-279, 1976.

[16] A. Kaplan and M. L. Maehr, "Enhancing the Motivation of African American StudentsL An Achievement Goal Theory Perspective," Journal of Negro Education, p. 23, 1999.

[17] V. Klymchuk, "The Motivational Dimesions of Live Events' Perception: Towards an Individual Motivational Mapping on SelfDetermiantion Theory basis," GESJ: Education Science and Psychology, p. 28, 2014.

[18] S. Kular, M. Gatenby, C. Rees, E. Soane and K. Truss, "Employee Engagement: A Literature Review," Kingston Business School Working Paper, pp. 1-23, October 2008.

[19] R. N. Lockwood, "Leveraging Employee Engagement for Competitive Advantage," SHRM Research, pp. 2-10, 2007.

[20] C. Maslach, S. W.B. and L. M.P., "Job Burnout," Annual Review of Psychology, pp. 397-422, 2001.

[21] J. P. Meyer and M. Gagne, "Employee Engagement From a SelfDetermination Theory Perspective," Industrial and Organizational Psychology, vol. 1, pp. 60-62, 2008.

[22] R. M. Ryan and E. L. Deci, "Intrinsic and Extrinsic Motivations: Classic Definitions and New Directions," Contemporary Educational Psychological, vol. 25, pp. 54-67, 2000.

[23] M. Saunders, P. Lewis and A. Thornhill, Research Methods for Business Students, Harlow: Pearson Education Limited, 2009.

[24] J. R. Schermerhorn, Organizational Behavior, USA: Atpala: Inc, 2007.

[25] V. W. Sujarweni, SPSS untuk Penelitian, Yogyakarta: Pustaka Baru Press, 2015.

[26] K. W. Thomas, Intrinsic Motivation at Work: What Really Drives Employee Engagement, 2nd Edition, Berret-Koehler Publisher, 2009.

[27] M. A. Tremblay, C. M. Blanchard, S. Taylor, L. G. Pelletier and M. Villeneuve, "Work Extrinsic and Intrinsic Motication Scale: Its Value for Organisation Psychology Research," Canadia Journal of Behavioral Science, vol. 41, no. 4, pp. 213-226, 2009.

[28] N. Urbach and F. Ahlemann, "Structural Equation Modeling in Information Systems Research Using Partial Least Square," Journal of Information Technology and Application, vol. 11, no. 2, pp. 5-40, 2010.

[29] D. Xanthopoulou, A. B. Bakker, A. Kantas and E. Demerouti, "Measuring burnout and work engagement: Factor structure, invarience, and latent mean differences across Greece and the Netherlands," Journal of Business Science and Applied Management, vol. 7, no. 2, pp. 40-52, 2012. 